\title{
LAPSELLE SUUNNATUN PUHEEN PIIRTEET JA NIIDEN YHTEYS SANASTON KEHITYKSEEN 24 JA 30 KUUKAUDEN IÄSSÄ
}

\author{
Leila Paavola-Ruotsalainen, Humanistinen tiedekunta / \\ Logopedian tutkimusyksikkö ja Lapsenkielen \\ tutkimuskeskus, Oulun yliopisto \\ Heta Kemppainen, Kuntoutusyksikkö / Puheterapia, \\ Kuopion kaupunki \\ Beda Luopajärvi, Etelä-Espoon lasten kuntoutuspalvelut, \\ Espoon kaupunki
}

\begin{abstract}
Tässä tutkimuksessa tarkasteltiin äitien ja 2-vuotiaiden lasten ( $N=12$ ) vapaita leikkitilanteita, joista analysoitiin lapselle suunnatun puheen piirteitä. Lapselle suunnatusta puheesta poimittiin responsiiviset ja ohjailevat ilmaukset sekä nimeämiset, laajennokset ja kielentämiset. Sen jälkeen tarkasteltiin kaikkien analysoitujen ilmaisutyyppien yhteyksiä toisiinsa. Lisäksi tutkittiin ilmaisutyyppien ja kahdessa ikäpisteessä, 24 ja 30 kuukauden iässä, mitatun lapsen sanaston tason välisiä yhteyksiä. Äitien ilmausten määrässä havaittiin paljon yksilöllistä vaihtelua. IImausten määrä korreloi positiivisesti responsiivisten ja kielentävien ilmausten määrään. Lisäksi responsiiviset ilmaukset korreloivat negatiivisesti sellaisten ohjailevien ilmausten kanssa, jotka suuntasivat lapsen huomiota uudelleen. Lapsen sanaston tason kannalta merkittävimmäksi äidin ilmaisutyypiksi nousivat laajennokset, joiden määrä korreloi positiivisesti myös responsiivisten ilmausten määrän kanssa. Nämä löydökset on hyvä huomioida puheterapeutin vastaanotolla, kun ohjataan puheen kehityksessä viivästyneen noin 2-3-vuotiaan lapsen vanhempia. Lapselle suunnatun puheen laadun ja sanaston kehityksen välistä yhteyttä on syytä tutkia lisää suuremmalla otoskoolla ja ottamalla huomioon vielä muitakin lapselle suunnatun puheen piirteitä.
\end{abstract}

Avainsanat: kehityksen tukeminen, lapselle suunnattu puhe, sanasto, vuorovaikutustyyli

Kirjoittajan yhteystiedot:

Leila Paavola-Ruotsalainen

Humanistinen tiedekunta / Logopedian

tutkimusyksikkö ja Lapsenkielen tutkimuskeskus

PL 1000, 90014 Oulun yliopisto

leila.paavola-ruotsalainen@oulu.fi

\section{JOHDANTO}

Erityisesti ensimmäisen ikävuoden lopussa ja toisen ikävuoden aikana sanasto on kehittyvän kielen keskeinen osa-alue (Bates, Dale \& Thal, 1995). Sanojen ymmärtämisen voidaan normaalitilanteessa odottaa alkavan 7-10 kuukauden iässä (Fenson ym., 1994; Harris, Yeeles, Chasin \& Oakley, 1995; Kuhl, 2007) 
tai jopa tätä aiemmin (Bergelson \& Swingley, 2012). Sanojen tuottaminen alkaa keskimäärin 12 kuukauden iässä (Clark, 2009, s. 14; Fenson ym., 1994; Stoel-Gammon, 2011), mutta yksilöllinen vaihtelu on suurta. Suomalaistutkimuksessa (Stolt, Haataja, Lapinleimu \& Lehtonen, 2008) lapset tuottivat 12 kuukauden iässä keskimäärin neljä sanaa, kun ymmärrettyjen sanojen keskiarvo oli jo 94. Lapsen varhaisen puheen kehityksen voidaan katsoa etenevän hitaasti, mikäli hänellä on 2-vuotiaana alle 50 tuotettua sanaa eikä ollenkaan sanayhdistelmiä (Rescorla, 1989; Zubrick, Taylor, Rice \& Slegers, 2007).

Yksilöllisiä eroja lasten sanaston kehityksessä on pyritty selittämään useilla erilaisilla tekijöillä, joista ihan varhaisvaiheen kehittymisessä on korostettu biologisia ja perinnöllisiä ja myöhäisemmässä kehityksessä kasvuympäristöön liittyviä tekijöitä (Harrison \& McLeod, 2010). Kielellisen syötteen, jolle lapsi altistuu, tiedetään olevan yhteydessä lasten välisiin eroihin varhaisessa sanaston kehityksessä (Bornstein, Tamis-LeMonda \& Haynes, 1999; Hoff, 2003; Pan, Rowe, Singer \& Snow, 2005). Vanhempien rooli kieliympäristön rakentajana on keskeinen, sillä he viettävät yleensä eniten aikaa lastensa kanssa, tuntevat heidät parhaiten ja heillä on emotionaalinen suhde lapsiinsa (WeitznerLin, 2004, s. 114). Pienelle lapselle suunnatusta puheesta käytetään alan kirjallisuudessa useita nimityksiä, kuten hoivakieli ja hoivapuhe (engl. motherese). Tarkasti ottaen hoivakieleksi tai hoivapuheeksi voidaan kutsua sellaista puhetta, joka on mukautettu hoivasävyiseksi ja jota aikuiset käyttävät etenkin puhuessaan pienille lapsille (Laalo \& Kunnari, 2012). Tässä artikkelissa käytetään termiä lapselle suunnattu puhe (engl. child-directed speech), sillä tämä käytäntö näyttää vakiintuneen englanninkieliseen tutkimuskirjallisuuteen. Lapselle suunnattu puhe on tärkeä tutkimusaihe, sillä siitä saadaan käytännön- läheistä tietoa, miten puheterapia-asiakkaina olevien pienten lasten vanhempia voidaan ohjata kiinnittämään huomiota sellaisiin oman puheensa piirteisiin, joiden tiedetään tukevan sanaston kehittymistä.

Lapselle suunnattua puhetta käsittelevissä tutkimuksissa huomio on kohdistunut pääosin äitien puheeseen, jota on tarkasteltu monenlaisista näkökulmista. Ensimmäiset tämän aiheen tutkimusraportit julkaistiin 1970-luvulla ja niissä huomion keskipisteessä olivat sanasto ja lauserakenteet (mm. Cross, 1977; Snow, 1977). Näissä tutkimuksissa havaittiin, että pienelle lapselle suunnatulle puheelle on leimaa-antavaa yksinkertaisuus, joka näkyy erityisesti lapsen kannalta helppojen sanojen, lyhyiden ilmausten ja rakenteeltaan yksinkertaisten lauseiden käyttönä. Sittemmin lapselle suunnatun puheen piirteissä, kuten puheen määrässä, vaihtelevuudessa ja monimutkaisuudessa, on kuitenkin havaittu huomattavaa yksilöllistä vaihtelua (Hurtado, Marchman \& Fernald, 2008). Rowen (2008) tutkimuksessa, jossa oli mukana myös yksi isä, joillakin vanhemmilla lapselle suunnattu puhe sisälsi jopa kymmenkertaisen määrän sanoja joihinkin toisiin vanhempiin verrattuna. Vanhemmat, jotka puhuivat enemmän, sanoivat myös enemmän erilaisia sanoja sekä tuottivat pidempiä lauseita puhuessaan lapselleen.

Kun tarkastellaan lapselle suunnattua puhetta kielen kehityksen tukemisen näkökulmasta, muun muassa Bornstein ym. (1999) ovat todenneet, että lapselle suunnatun puheen sovittaminen riittävän yksinkertaiseksi lapsen sen hetkiseen kielelliseen tasoon on keskeistä (ks. myös Landry, Smith \& Swank, 2006). Joidenkin tutkijoiden mukaan lapselle suunnatussa puheessa käytettyjen sanojen monipuolisuus olisi tärkeä tekijä (Huttenlocher, Waterfall, Vasilyeva, Vevea \& Hedges, 2010). Lapselle suunnattua puhetta ja sen merkitystä kielen kehityksen kannalta on tutkittu myös tarkastelemalla sanojen määriä. 
Hurtadon ym. (2008) tutkimuksen mukaan sanojen suuri määrä edesauttaa lapsen sanaston kehittymistä, mutta aiemmin raportoidussa Girolametton, Weitzmanin, Wiigsin ja Pearcen (1999) tutkimuksessa vastaavaa tulosta ei löytynyt. Osa tutkijoista on puolestaan luokitellut äitien ilmauksia erilaisten kriteerien perusteella ja tarkastellut niiden roolia lasten sanaston kehityksessä. Esimerkiksi Masur, Flynn ja Eichorst (2005) luokittelivat äitien ilmauksia responsiivisiin ja ohjaileviin, Namy ja Nolan (2004) poimivat nimeävät ilmaukset tarkempaan tarkasteluun kun taas Rowe (2012) luokitteli lapselle suunnatun puheen selittäviin, kertoviin ja leikillisiin/ mielikuvituksellisiin ilmauksiin.

Snow (1995) on esittänyt, että lapselle suunnatun puheen sisällön sovittaminen lapsen sen hetkiseen kielelliseen tasoon ei riitä tukemaan pienen lapsen kehitystä, mikäli puhe on hyvin ohjailevaa ja pyrkii jatkuvasti suuntaamaan lapsen huomion uusiin kohteisiin. Itse asiassa jatkuvilla lapsen huomiota uudelleen suuntaavilla ilmauksilla on todettu olevan yhteyttä hitaampaan varhaisen sanaston kehitykseen (Akhtar, Dunham \& Dunham, 1991; Della Corte, Benedict \& Klein, 1983; Masur ym., 2005). Sen sijaan responsiivisuuden eli kyvyn vastata lapsen aloitteisiin nopeasti, johdonmukaisesti ja tarkoituksenmukaisesti lapsen aikomuksia ja tunteita oikein tulkiten on usean tutkimuksen mukaan todettu tukevan sanaston kehitystä (Bornstein ym., 1999; Girolametto ym., 1999, 2002; Hoff \& Naigles, 2002; Kaiser \& Hancock, 2003; Masur ym., 2005; Paavola, 2006; Roberts \& Kaiser, 2011). Herkkä reagoiminen lapsen ilmaisuihin rohkaisee lasta kommunikoimaan ja tarjoaa tilanteeseen liittyvän kielellisen mallin (Kaiser \& Hancock, 2003). Responsiiviselle vuorovaikutustyylille on niin ikään tyypillistä pyrkimys jakaa yhteinen huomion kohde lapsen kanssa. Lapselle suunnattu puhe, joka jatkaa lapsen tarkkaavuuden kohdistamista aiheeseen, aktivoi lisää lapsen jo oppimaa sanastoa (Bornstein ym., 1999; Masur ym., 2005). Responsiivista ja ohjailevaa vuorovaikutustyyliä on monesti pidetty toisilleen vastakkaisina. Flynn ja Masur (2007) sekä Lloyd ja Masur (2014) eivät kuitenkaan näe asiaa näin yksioikoisena. He katsovat, että lapselle suunnattuja toimintaa ohjaavia ilmauksia tulee tarkastella jaetun tarkkaavuuden näkökulmasta. Ohjaukset, jotka liittyvät lapsen huomion kohteeseen, saattavat tukea kielellistä kehitystä aivan kuten vastaukset lapsen aloitteisiin esimerkiksi tilanteessa olevia asioita, tapahtumia tai tunteita kuvailemalla. Rowe (2008) on puolestaan esittänyt, että ohjaileva vuorovaikutustyyli saattaa heijastua myös lapselle suunnatun puheen määrän ja sanastoon. Hänen tutkimuksessaan vanhemmat, jotka käyttivät enemmän ohjailevia ilmauksia, sanoivat vähemmän sanoja ja käyttivät yksipuolisempaa sanastoa kuin vanhemmat, jotka käyttivät vähemmän lapsensa käyttäytymistä ohjaavia ilmauksia. Alan tutkimuksissa olisikin hyödyllistä tarkastella lapselle suunnattua puhetta monipuolisesti eri näkökulmista (esimerkiksi ilmausten määrän ja erilaisten ilmaisutyyppien yhteyksiä toisiinsa).

Varhaisessa puheen kehityksessä viivästyneille noin 2-3 vuotiaille lapsille tarkoitetuissa vanhempilähtöisissä kuntoutusohjelmissa, joista tunnetuin lienee Hanen It Takes Two to Talk (Pepper \& Weitzman, 2004), vanhempia ohjataan nimeämään ympärillä olevia esineitä ja asioita, laajentamaan lapsen ilmaisuyrityksiä ja kielentämään käsillä olevaa tilannetta. Nimeämisen määrän on todettu olevan merkityksellisintä siinä vaiheessa, kun lapsen sanavarasto on pieni (Tan \& Schafer, 2005) tai lapsi on vielä yksisanavaiheessa (Cable \& Domsch, 2011). Namyn ja Nolanin (2004) tutkimus osoitti, että niillä lapsilla, joiden vanhempien nimeävät ilmaisut lisääntyivät lapsen toisen ikävuoden aikana, oli sanaston kasvu hitaampaa ja sanaston koko pienempi 
kuin niillä lapsilla, joiden vanhempien nimeävien ilmausten käyttö väheni, säilyi samana tai oli suurimmillaan 18 kuukauden iässä. Kun aikuinen lisää lapsen ilmaisuun tai kommunikointiyritykseen tietoa, on kyseessä laajennos (Weitzner-Lin, 2004, s. 100). Laajentaminen voi olla myös lapsen ilmaisun muokkaamista kieliopilliseen muotoon. Lapset oppivat uusia sanoja, kun heidän omia ilmaisujaan muotoillaan uudelleen eli niistä rakennetaan tarkempia malleja välittömässä kontekstissa (Hoff \& Naigles, 2002; Kaiser \& Hancock, 2003; Roberts \& Kaiser, 2011; Wing ym., 2007). Kielentämisellä puolestaan tarkoitetaan sitä, kun aikuinen kuvaa tai kertoo lapsen käynnissä olevasta toiminnasta sanoin (Weitzner-Lin, 2004, s. 101). Aikuinen voi kielentää myös lapsen tunteita ja tahtoa tai omaa toimintaansa. Tällaisissa tilanteissa lapsen on mahdollista kuulla tilanteeseen liittyvää kieltä ilman, että hänen tarvitsee vastata siihen (Vigil, Hodges \& Klee, 2005). Kielentäminen tukee lapsen kielellistä ja ei-kielellistä päättelykykyä sekä auttaa ylläpitämään tarkkaavuutta (Smith, Landry \& Swank, 2000).

Vanhemman ja lapsen vuorovaikutusta luonnehtii dynaamisuus ja vastavuoroisuus, jolloin vanhemman toiminta vaikuttaa lapsen toimintaan ja päinvastoin ( $\mathrm{mm}$. Launonen, 2007, s. 20; Weitzner-Lin, 2004, s. 54). On esimerkiksi havaittu, että vanhemmat käyttävät monimutkaisempaa puhetta ja monipuolisempaa sanastoa, kun lapsi kasvaa ja tämän kieli kehittyy (Huttenlocher ym., 2010; Pan ym., 2005; Rowe, 2012). Yksilöllisillä eroilla lasten kehityksessä ja vuorovaikutuksen aikaisessa toiminnassa saattaa olla merkitystä siinä, minkälaiseksi lapselle suunnattu puhe muotoutuu. Aiheen tutkimus on tärkeää siksi, että yksilölliset erot varhaisessa sanaston kehityksessä ovat merkittävät (Clark, 2009, s. 14; Fenson ym., 1994; Stoel-Gammon, 2011; Stolt ym., 2008). Lisäksi on huomionarvoista, että tietty lapselle suunnatun puheen piirre saattaa olla jossain vaiheessa merkityksellinen lapsen puheen kehitykselle, mutta myöhemmin vastaavaa funktiota ei välttämättä ole (mm. Rowe, 2012; Soderstrom, 2007). Esimerkiksi Rowe on todennut, että lapselle suunnatun puheen määrä on merkityksellisintä lapsen toisen elinvuoden aikana, kun taas myöhemmin korostuu lapselle suunnatussa puheessa käytetyn sanaston monipuolisuuden merkitys.

Tässä tutkimuksessa tarkastellaan lasten sanaston tasoa 24 ja 30 kuukauden iässä sekä 24 kuukauden ikäiselle lapselle suunnatun puheen piirteitä kahden erilaisen luokitteluanalyysin avulla. Kyseinen ikäpiste on tärkeä arvioitaessa, onko varhaisessa puheen kehityksessä viivettä, ja näin ollen puheterapeutin on tarvittaessa osattava tässä vaiheessa myös opastaa vanhempia. Sekä lapsen sanastoa arvioivien että lapselle suunnatun puheen piirteitä kuvaavien muuttujien osalta tutkitaan myös mahdollisia eroja tyttöjen ja poikien välillä. Ensimmäisessä lapselle suunnatun puheen luokitteluanalyysissa huomio kohdistetaan responsiivisuuteen, ohjailevuuteen ja siihen, miten äiti pyrkii jakamaan yhteisen huomion kohteen lapsen kanssa. Toisessa analyysissa keskitytään nimeäviin, laajentaviin ja kielentäviin ilmauksiin. Tulososassa raportoidaan lapselle suunnatusta puheesta poimittujen eri ilmaisutyyppien määrät ja ilmausten kokonaismäärä. Lisäksi tutkitaan kaikkien tarkasteltavien lapselle suunnatun puheen piirteiden yhteyksiä paitsi toisiinsa myös lasten sen hetkiseen ja puoli vuotta myöhempään sanaston tasoon.

\section{MENETELMÄT}

\section{Tutkittavat}

Tutkimukseen osallistui 12 lasta äiteineen, jotka oli rekrytoitu neuvolatarkastusten yhteydessä, perhekahviloista tai sosiaalisen 
median kautta. Neuvolan terveydenhoitajille annettiin tieto poissulkukriteereistä sekä suullisesti että kirjallisesti ja lisäksi lasten vanhemmat täyttivät taustatietolomakkeen. Osallistumisen vaatimuksena oli, että lapsi oli suomenkielinen ja asui biologisten vanhempiensa tai vähintään biologisen äitinsä kanssa. Lapsen tuli olla syntynyt täysiaikaisena $(38+v k)$. Hänellä ei saanut olla todettua kehitysvammaa, suun ja nielun anomalioita (esim. huuli-suulakihalkio) eikä selviä neurologisia ongelmia, eikä myöskään epäilyä kuulon alenemasta. Myös lapsen tunneilmaisun, katsekontaktin ja vastavuoroisuuden tuli vanhempien arvioiden perusteella olla kehittynyt vähintään tyypillisen kehityksen rajoissa.

Vanhemmille annetussa tiedotteessa kerrottiin, että tutkimukseen osallistuminen oli vapaaehtoista ja että suostumus oli mahdollista peruuttaa missä tutkimuksen vaiheessa tahansa. Vanhemmille on niin ikään kerrottu, että tutkimuksen aineisto käsitellään ehdottoman luottamuksellisesti niin, ettei tutkittavien henkilöllisyys paljastu missään vaiheessa ulkopuolisille.

\section{Lapsen sanastoa mittaavat arviointimenetelmät}

Tutkimuksessa käytettiin kahta lapsen sanaston tasoa mittavaa kuvasanavarastotestiä. Testit on alun perin kehitetty ja normitettu Yhdysvalloissa (Martin \& Brownell, 2010ab). Tässä tutkimuksessa käytetyn aineiston keräämiseen käytettiin Kunnarin ja Välimaan (2011) kyseisistä menetelmistä suomenkieleen soveltamia, toistaiseksi vain tutkimuskäytössä olevia testilomakkeita. Testaukset toteutettiin lasten ollessa 24 ja 30 kuukauden ikäisiä. ROWPVT-4 (Receptive One-Word Picture Vocabulary Test - 4) on ymmärtävän sanaston arviointiin käytettävä kuvasanavarastotesti (Martin \& Brownell, 2010b). Siinä on yhteensä 190 osiota, joissa tutkittava valitsee neljästä vaihtoehtokuvasta arvioijan tuottamaa sanaa vastaavan kuvan. Arvioiminen aloitetaan tutkittavan kronologisen iän mukaisesta kohdasta ja sitä jatketaan, kunnes kahdeksassa peräkkäisessä osiossa on tullut kuusi virhettä. EOWPVT-4 (Expressive One-Word Picture Vocabulary Test - 4) on puolestaan tuottavan sanaston arvioinnissa käytettävä kuvasanavarastotesti, joka sisältää 190 esineitä, toimintaa ja käsitteitä esittävää värikuvaa, jotka tutkittavan on tarkoitus nimetä kuvan esittämisen jälkeen (Martin \& Brownell, 2010a). Arvioiminen aloitetaan kronologista ikää vastaavasta kuvasta, ja kuvien esittämistä jatketaan, kunnes tutkittava vastaa väärin kuuteen peräkkäiseen osioon.

\section{Äidin ilmaisutyyppien analyysi}

Lapsia ja heidän äitejään videoitiin vapaissa leikkitilanteissa perheiden kotona noin 20 minuuttia, josta tässä tutkimuksessa litteroitiin ja analysoitiin 15 minuuttia kustakin alkaen nauhoituksen toisesta minuutista. Analysoitavaa aineistoa oli siis yhteensä 180 minuuttia. Leikkitilanteissa oli käytössä tietty ikätasoa vastaava lelumateriaali ( $\mathrm{mm}$. rakennuspalikoita, nukke ja leikkiastioita). Nauhoitukset tehtiin lasten ollessa 24 kuukauden ikäisiä.

Päävastuu litterointi- ja analysointikäytänteiden sovittamisesta tämän tutkimuksen aineistoon oli ensimmäisellä kirjoittajalla, jonka koordinoimana ja opastamana toinen ja kolmas kirjoittaja työskentelivät. Litteroinnissa pyrittiin yhdenmukaisuuteen sopimalla yhteisiä litterointisääntöjä myös koko työryhmän kesken ilmausten rajojen selkeyttämiseksi. Leikkitilanteet litteroitiin siten, että kaikki puhutut ilmaukset kirjattiin ylös ja lisäksi kaikki sellainen ei-kielellinen toiminta, joka oli toiselle suunnattua tai muulla tavalla toimi vuorovaikutuksen aloittajana tai ylläpitäjänä (esim. lapsen leikkitoiminto, johon 
äiti vastasi kommentoimalla sitä). Äidin osalta mahdollinen muu kuin lapselle suunnattu puhe jätettiin litteraattien ulkopuolelle. Äidin ja lapsen toiminta jaettiin vuoroihin. Kukin vuoro sisälsi joko puhuttuja ilmauksia tai ei-kielellistä toimintaa tai molempia niistä. Yhdessä vuorossa saattoi olla monta ilmausta. Äidin ja lapsen puhe jaettiin ilmauksiin siten, että huomioon otettiin puheen kieliopillinen muoto, intonaatio sekä puheessa olevat tauot. Lisäksi kustakin videonauhoitteesta analysoitiin kolmen minuutin katkelma kahden arvioitsijan toimesta (yhteensä $20 \%$ kokonaisaineistosta). Luotettavuusprosentiksi vuorojen ja ilmausten rajojen osalta saatiin 95,5\% (yhtäläisesti jaettujen vuorojen ja ilmausten määrä $\div$ yhtäläisesti ja eriävästi jaettujen vuorojen ja ilmausten yhteenlaskettu määrä).

Tämän jälkeen litteraattien avulla laskettiin äitien puhuttujen ilmausten kokonaismäärä ja lisäksi ne luokiteltiin kahdella erilaisella tavalla. Litteraattien analysoinnissa huomioitiin sekä äidin että lapsen puhutut ilmaukset kuin myös äidin ja lapsen ei-kielellinen toiminta sekä vuorot, sillä ne kaikki olivat tärkeitä rajaavia tekijöitä äidin ilmausten luokittelussa. Ensimmäisessä luokitteluanalyysissa (analyysi 1) huomio kiinnitettiin siihen, miten äidin ilmaukset liittyivät lapsen edellä olevaan ilmaukseen, huomion kohteeseen tai meneillään olevaan toimintaan ja mitä äiti pyrki ilmauksellaan saamaan aikaan (esim. rajoittamaan lapsen toimintaa). Ensimmäisen analyysin ilmaisuluokat perustuvat Flynnin ja Masurin (2007) esittämään analyysimalliin. Toisessa luokittelussa (analyysi 2) äitien ilmauksista poimittiin sellaiset, jotka voidaan määritellä nimeämiseksi, laajennokseksi tai kielentämiseksi. Esimerkiksi tunnetussa Hanen It Takes Two to Talk -kuntoutusohjelmassa (Pepper \& Weitzman, 2004) vanhempia ohjataan käyttämään näitä kolmea ilmaisutyyppiä lapselle suunnatussa puheessa. Molemmissa analyyseissa käytettyjen ilmaisuluokkien mää- ritelmät on esitetty taulukossa 1 . Valittujen luokkien ulkopuolelle jäävät muut ilmaukset huomioitiin tässä tutkimuksessa vain laskettaessa ilmausten kokonaismäärï.

Analyysit työstettiin ja luokittelukriteerit määriteltiin myös aineistolähtöisesti koko työryhmän yhteistyöllä. Analyysin 1 toteutuksesta vastasi kolmas kirjoittaja ja hänen luokittelunsa luotettavuuden arvioinnissa toinen kirjoittaja ristiinluokitteli $20 \%$ kokonaisaineistosta. Yhtäläisyysprosentti oli 95,2\% (yhtäläisesti luokitellut ilmaukset $\div$ yhtäläisesti ja eriävästi luokiteltujen ilmausten yhteenlaskettu määrä).

Analyysin 2 toteutti toinen kirjoittaja. Siinä eri ilmaisuluokkien välinen rajanveto oli osittain häilyvää, minkä vuoksi päätettiin, että ilmaus sisällytetään siihen luokkaan, johon se eniten kolmesta vaihtoehdosta kuuluu. Ensimmäisen ja toisen kirjoittajan yhteisissä datasessioissa ilmaisuluokkien välisiä rajoja tarkennettiin useita kertoja, kunnes epäselvienkin kohtien osalta päästiin yksimielisyyteen. Tarkennusten jälkeen eri luokkien määritelmät ja luokkien väliset rajaukset pyrittiin kirjaamaan mahdollisimman tarkasti. Aineisto käytiin läpi useita kertoja, jotta yhdessä sovitut tarkennukset tulivat varmasti huomioiduiksi koko aineistossa. Ilmauksen muodon lisäksi tarkasteltiin ilmauksen sisältöä sekä tilannetta, jossa ilmaus sanottiin. Esimerkiksi laajentamisen ja kielentämisen välinen ero oli joissakin tapauksissa häilyvä. Niiden erottavaksi tekijäksi määriteltiin, että kielentämisessä ei ollut taustalla lapsen tuottamaa ilmausta. Edellä mainittujen asioiden lisäksi tutkimuksen luotettavuutta vahvistettiin sillä, että molempien analyysien päävastuulliset tekijät näkivät kuvasanavarastotestien pistemäärät vasta siinä vaiheessa, kun luokittelut oli tehty. Lasten testaamisesta ja lomakkeiden pisteytyksestä vastasi ensimmäinen kirjoittaja. 
Taulukko 1. Äidin ilmaisuluokkien kuvaukset.

\begin{tabular}{|c|c|}
\hline \multicolumn{2}{|l|}{ IImaisuluokka } \\
\hline \multicolumn{2}{|l|}{ Analyysi 1} \\
\hline $\begin{array}{l}\text { Responsiiviset } \\
\text { ilmaukset }\end{array}$ & $\begin{array}{l}\text { Äidin sellaiset vastailmaukset lapsen toimintaan tai ääntelyyn, joiden } \\
\text { tarkoituksena on ylläpitää lapsen huomion kohdetta ja mielenkiintoa } \\
\text { keskustelussa. Tähän luokkaan kuuluu myös lapsen välittömässä } \\
\text { lähiympäristössä olevien asioiden ja esineiden nimeäminen tai } \\
\text { mielenkiinnon kohdetta kuvailevat ja kommentoivat ilmaukset, jotka } \\
\text { voivat olla myös kysymysmuotoisia. Myös sosiaaliset ilmaukset, kuten } \\
\text { kiitos, ole hyvä ja anteeksi kuuluvat tähän luokkaan. }\end{array}$ \\
\hline $\begin{array}{l}\text { Toimintaa tukevat } \\
\text { ilmaukset }\end{array}$ & $\begin{array}{l}\text { Pragmaattisen tarkoitteen vuoksi ohjauksiksi määriteltävät ilmaukset } \\
\text { eli ehdotukset, käskyt ja kehotukset, jotka liittyvät lapsen sen } \\
\text { hetkiseen huomion kohteeseen. Tähän luokkaan kuuluvat myös } \\
\text { yhteiseen huomion kohteeseen liittyvät ilmaukset, joilla äiti rohkaisee } \\
\text { ja kannustaa lasta toimintaan ja vuorovaikutukseen. Lisäksi kaikki } \\
\text { edellä kuvatut ilmaukset tilanteissa, joissa lapsi ei ole valmiiksi } \\
\text { suunnannut huomiotaan tarkasti tiettyyn kohteeseen, ja äiti suuntaa } \\
\text { lapsen huomion, kuuluvat tähän luokkaan. }\end{array}$ \\
\hline $\begin{array}{l}\text { Toimintaa } \\
\text { kontrolloivat } \\
\text { ilmaukset }\end{array}$ & $\begin{array}{l}\text { Ehdotukset, käskyt ja kehotukset, joilla äiti pyrkii ohjaamaan lapsen } \\
\text { toimintaa pois lapsen sen hetkisestä huomion kohteesta. Ilmaukset } \\
\text { ovat lapsen toimintaa kontrolloivia, rajoittavia ja ohjaavia. }\end{array}$ \\
\hline $\begin{array}{l}\text { Huomiota uudelleen } \\
\text { suuntaavat } \\
\text { ilmaukset }\end{array}$ & $\begin{array}{l}\text { Tähän luokkaan kuuluvilla ilmauksilla äiti pyrkii ohjaamaan lapsen } \\
\text { huomiota johonkin toiseen kohteeseen kuin mihin lapsen sen } \\
\text { hetkinen huomio on suuntautunut. Yleisiä tähän luokkaan kuuluvia } \\
\text { ilmauksia ovat houkuttelu ja kohteen kuvailu. }\end{array}$ \\
\hline \multicolumn{2}{|l|}{ Analyysi 2} \\
\hline Nimeämiset & $\begin{array}{l}\text { Ilmaukset, joilla äiti nimeää leikkitilanteessa mukana olevia } \\
\text { konkreettisia, havaittavissa olevia esineitä ja asioita. Ilmaukset } \\
\text { eivät sisällä muuta informaatiota. Nimettävien kohteiden tulee olla } \\
\text { substantiiveja. }\end{array}$ \\
\hline Laajennokset & $\begin{array}{l}\text { Ilmaukset, joissa äiti korjaa lapsen edellä tuottaman ilmauksen } \\
\text { kieliopillista muotoa ja/tai lisää lapsen ilmaukseen samaan } \\
\text { aiheeseen liittyvää informaatiota. Lisäksi tähän luokkaan kuuluvat } \\
\text { ilmaukset, joissa äiti tarjoaa lapsen ilmaukseen lisäinformaatiota } \\
\text { korjaamalla lapsen tuottaman ilmauksen äänteellisesti oikeaksi. }\end{array}$ \\
\hline Kielentämiset & $\begin{array}{l}\text { Ilmaukset, jotka kertovat meneillään olevasta tai juuri alkaneesta } \\
\text { lapsen tai äidin omasta toiminnasta, kuvailevat leikkitilanteessa } \\
\text { mukana olevia esineitä tai niiden paikkaa tai kuvaavat lapsen tai } \\
\text { äidin itsensä tunteita, tahtoa tai olotilaa ja liittyvät meneillään } \\
\text { olevaan tilanteeseen. Luokkaan kuuluvat myös sellaiset meneillään } \\
\text { olevaan toimintaan tai tilanteeseen liittyvät ilmaukset, jotka pyrkivät } \\
\text { rikastuttamaan kuvitteellista leikkiä tai kuvailevat leikillisesti } \\
\text { erilaisten leluhahmojen haluja ja tunteita, esimerkiksi "nukellaki on } \\
\text { jano". }\end{array}$ \\
\hline
\end{tabular}




\section{Tilastollinen analyysi}

Tilastollinen analyysi tehtiin IBM SPSS Statistics 23 -ohjelmalla. Lapsille tehtyjen kuvasanavarastotestien pistemääristä, äitien ilmausten kokonaismärästä ja myös eri ilmaisuluokkien osalta laskettiin keskiluvut (keskiarvo, mediaani, keskihajonta sekä minimi- ja maksimiarvot). Koska ilmausten kokonaismäärä vaihteli varsin huomattavasti, äitien eri ilmaisuluokkien osalta huomioitiin absoluuttisten määrien lisäksi suhteelliset osuudet (tiettyyn luokkaan kuuluvien ilmaisujen määrä $\div$ kaikkien lapselle suunnattujen ilmaisujen määrä). Muuttujien jakaumia tarkasteltiin histogrammien avulla sekä Shapiro-Wilkin -testillä. Koska aineisto on pieni ja osa muuttujista jakaumaltaan vinoja, tilastolliseen analyysiin valittiin epäparametriset menetelmät. Tyttöjen ja poikien välisiä eroja sekä sanastomuuttujien että äidin ilmausten osalta tarkasteltiin Mann-Whitneyn U-testillä. Wilcoxonin merkittyjen sijalukujen testiä käytettiin, kun tarkasteltiin iän myötä tapahtunutta muutosta sanastotestien tuloksissa. Lapselle suunnatun puheen erilaisten piirteiden välisiä yhteyksiä tutkittiin Spearmanin järjestyskorrelaatiokertoimen avulla. Näin tehtiin myös tarkasteltaessa äidin ilmaisujen ja lasten sanaston tason välisiä yhteyksiä.

\section{TULOKSET}

Lasten ymmärtävä ja tuottava sanasto 24 ja 30 kunkauden iässä

Taulukkoon 2 on listattu sekä ymmärtävän (ROWPVT) että tuottavan (EOWPVT) sanaston tasoa mittaavien testien tulokset $24 \mathrm{ja}$ 30 kuukauden iässä. Testipisteet kasvavat iän myötä. Wilcoxonin sijalukutestin perusteella iän myötä tapahtunut kasvu testipisteissä on tilastollisesti merkitsevä sekä reseptiivisessä $(\mathrm{Z}=2,982, \mathrm{p}=0,003)$ että ekspressiivisessä kuvasanavarastotestissä $(\mathrm{Z}=2,936, \mathrm{p}=$ $0,003)$. Hajonta tutkittavien henkilöiden tulosten välillä on kuitenkin huomattavankin suurta molemmissa ikäpisteissä. Tyttöjen ja poikien väliltä löytyi yksi tilastollisesti merkitsevä ero: 24 kuukauden iässä tytöt saivat enemmän pisteitä ymmärtävää sanastoa mittaavasta testistä kuin pojat $(\mathrm{U}=31,000, \mathrm{Z}=$ $2,082, \mathrm{p}=0,037)$. Tyttöjen mediaaniarvo oli 23,50 ja poikien 18,50 . Muissa sanavarastoa mittaavissa muuttujissa ei löytynyt eroja tyttöjen ja poikien välillä.

Taulukko 2. Kuvasanavarastotestien keskiluvut 24 ja 30 kuukauden iässä.

\begin{tabular}{|l|l|l|l|l|l|}
\hline & ka & md & s & min & max \\
\hline 24 kk & & & & & \\
ROWPVT & 22,75 & 22 & 7,25 & 14 & 42 \\
EOWPVT $^{2}$ & 15,50 & 18 & 8,44 & 0 & 27 \\
\hline 30 kk $^{2}$ & & & & & \\
ROWPVT $^{1}$ & 36,83 & 36,50 & 7,76 & 23 & 49 \\
EOWPVT $^{2}$ & 26,83 & 29,00 & 12,54 & 7 & 47 \\
\hline
\end{tabular}

Huom. ${ }^{1}$ Receptive One-Word Picture Vocabulary Test $-4,{ }^{2}$ Expressive One-Word Picture Vocabulary Test $-4, \mathrm{ka}=$ keskiarvo, $\mathrm{md}=$ mediaani, $\mathrm{s}=$ keskihajonta, $\min =$ minimiarvo, $\max =$ maksimiarvo 


\section{Äidin erilaisten ilmausten ybteydet toisiinsa}

Seuraavaksi tarkastellaan äidin erilaisten ilmausten yhteyksiä toisiinsa. Ensimmäiseksi esitetään näiden muuttujien keskiluvut ( $\mathrm{ks}$. taulukko 3). Muut ilmaukset on tässä tutkimuksessa huomioitu vain laskettaessa ilmausten kokonaismääriä. Äidin responsiivisuutta ja ohjailevuutta mittaavien muuttujien (analyysi 1) osalta responsiivisia ilmauksia esiintyi selkeästi eniten. Sekä toimintaa kontrolloivia että huomiota uudelleen suuntaavia ilmauksia oli tässä aineistossa vähän. Analyysin 2 osalta voidaan mainita, että kielentämisiä oli selkeästi eniten ja nimeämisiä vähiten.
Äitien lapselle suunnattujen ilmausten määrän suuri vaihtelu on huomionarvoista. Ilmausten kokonaismäärä oli suurimmillaan 297 ja pienimmillään yli puolet vähemmän eli 133. Keskimäärin ilmauksia oli 192,42 (md $=172,00, s=51,60)$. Positiivisia tilastollisesti merkitseviä yhteyksiä löytyi ilmaisujen kokonaismäärän ja responsiivisten ilmausten ( $\mathrm{rs}=0,697, \mathrm{p}=0,012)$, toimintaa tukevien ilmausten ( $r s=0,667, p=0,018)$ ja kielentävien ilmausten ( $\mathrm{rs}=0,886, \mathrm{p}<0,0001)$ määrän välillä. Lapsen sukupuoli ei sen sijaan ollut yhteydessä äidin ilmausten määrään tai tyyppeihin.

Taulukko 3. Äidin ilmaisuluokkien keskiluvut (suhteelliset osuudet suluissa).

\begin{tabular}{|c|c|c|c|c|c|}
\hline IImaisuluokka & ka & md & s & $\min$ & $\max$ \\
\hline \multicolumn{6}{|l|}{ Analyysi 1} \\
\hline Responsiiviset ilmaukset & $\begin{array}{l}118,42 \\
(0,62)\end{array}$ & $\begin{array}{l}103,50 \\
(0,64)\end{array}$ & $\begin{array}{l}37,39 \\
(0,09)\end{array}$ & $\begin{array}{l}70 \\
(0,42)\end{array}$ & $\begin{array}{l}188 \\
(0,74)\end{array}$ \\
\hline Toimintaa tukevat ilmaukset & $\begin{array}{l}40,75 \\
(0,21)\end{array}$ & $\begin{array}{l}35,50 \\
(0,21)\end{array}$ & $\begin{array}{l}20,49 \\
(0,06)\end{array}$ & $\begin{array}{l}15 \\
(0,11)\end{array}$ & $\begin{array}{l}88 \\
(0,30)\end{array}$ \\
\hline $\begin{array}{l}\text { Toimintaa kontrolloivat } \\
\text { ilmaukset }\end{array}$ & $\begin{array}{l}2,42 \\
(0,01)\end{array}$ & $\begin{array}{l}1,00 \\
(0,01)\end{array}$ & $\begin{array}{l}3,06 \\
(0,02)\end{array}$ & $\begin{array}{l}0 \\
(0,00)\end{array}$ & $\begin{array}{l}10 \\
(0,05)\end{array}$ \\
\hline $\begin{array}{l}\text { Huomiota uudelleen suuntaavat } \\
\text { ilmaukset }\end{array}$ & $\begin{array}{l}5,75 \\
(0,03)\end{array}$ & $\begin{array}{l}3,50 \\
(0,02)\end{array}$ & $\begin{array}{l}6,84 \\
(0,04)\end{array}$ & $\begin{array}{l}0 \\
(0,00)\end{array}$ & $\begin{array}{l}25 \\
(0,13)\end{array}$ \\
\hline Muut ilmaukset & $\begin{array}{l}24,33 \\
(0,13)\end{array}$ & $\begin{array}{l}21,00 \\
(0,13)\end{array}$ & $\begin{array}{l}10,03 \\
(0,05)\end{array}$ & $\begin{array}{l}13 \\
(0,06)\end{array}$ & $\begin{array}{l}47 \\
(0,24)\end{array}$ \\
\hline \multicolumn{6}{|l|}{ Analyysi 2} \\
\hline Nimeämiset & $\begin{array}{l}4,67 \\
(0,02)\end{array}$ & $\begin{array}{l}4,00 \\
(0,02)\end{array}$ & $\begin{array}{l}4,70 \\
(0,02)\end{array}$ & $\begin{array}{l}0 \\
(0,00)\end{array}$ & $\begin{array}{l}18 \\
(0,08)\end{array}$ \\
\hline Laajennokset & $\begin{array}{l}13,25 \\
(0,07)\end{array}$ & $\begin{array}{l}14,00 \\
(0,08)\end{array}$ & $\begin{array}{l}9,00 \\
(0,04)\end{array}$ & $\begin{array}{l}0 \\
(0,00)\end{array}$ & $\begin{array}{l}28 \\
(0,13)\end{array}$ \\
\hline Kielentämiset & $\begin{array}{l}56,75 \\
(0,30)\end{array}$ & $\begin{array}{l}55,00 \\
(0,29)\end{array}$ & $\begin{array}{l}18,97 \\
(0,06)\end{array}$ & $\begin{array}{l}32 \\
(0,20) \\
\end{array}$ & \begin{tabular}{|l|}
86 \\
$(0,40)$
\end{tabular} \\
\hline Muut ilmaukset & $\begin{array}{l}117,75 \\
(0,61)\end{array}$ & $\begin{array}{l}113,50 \\
(0,62)\end{array}$ & $\begin{array}{l}33,13 \\
(0,07)\end{array}$ & $\begin{array}{l}71 \\
(0,52)\end{array}$ & \begin{tabular}{|l|}
179 \\
$(0,73)$
\end{tabular} \\
\hline
\end{tabular}

Huom. ka = keskiarvo, $\mathrm{md}=$ mediaani, $\mathrm{s}=$ keskihajonta, $\min =$ minimiarvo, $\max =$ maksimiarvo 
Taulukossa 4 esitetään äidin eri ilmaisuluokkien väliset korrelaatiot. Yhteyksiä tarkastellaan erikseen ilmaisuluokkien absoluuttisten määrien ja suhteellisten osuuksien osalta. Responsiiviset ilmaukset olivat negatiivisesti yhteydessä toimintaa kontrolloivien ilmausten kanssa ja positiivisesti yhteydessä nimeävien, laajentavien ja kielentävien ilmausten kanssa. Näistä yhteyksistä viimeinen ei kuitenkaan tullut esille, kun tarkasteltiin ilmaisuluokkien suhteellisia osuuksia eli kontrolloitiin ilmausten kokonaismäärää. Lisäksi suhteellisten osuuksien tarkastelussa löytyi negatiivinen yhteys responsiivisten ja huomiota uudelleen suuntaavien ilmausten väliltä. Toimintaa kontrolloivien ja huomiota uudelleen suuntaavien ilmausten väliltä löytyi voimakas positiivinen korrelaatio. Lisäksi Spearmanin järjestyskorrelaatiokerroin osoitti negatiivisen yhteyden toimintaa kontrolloivien ilmausten ja nimeämisten välillä, samoin kuin huomiota uudelleen suuntaavien ilmausten ja nimeämisten välillä. Näistä edellä mainittu yhteys oli kuitenkin vain suuntaa antava, kun käytettiin suhteellisia osuuksia. Nimeävien ilmausten ja kielentämisten määrän välillä oli positiivinen korrelaatio, kun tarkasteltiin absoluuttisia lukuja. Sen sijaan toimintaa tukevien ilmausten ja muiden ilmaisuluokkien väliltä ei löytynyt yhtään tilastollisesti merkitsevää yhteyttä.

Taulukko 4. Spearmanin järjestyskorrelaatiokertoimet äidin ilmaisuluokkien välillä ( $p$-arvot suluissa).

\begin{tabular}{|c|c|c|}
\hline Ilmaisuluokka & Absoluuttiset luvut & Suhteelliset osuudet \\
\hline \multicolumn{3}{|l|}{ Responsiiviset ilmaukset ja } \\
\hline toimintaa tukevat ilmaukset & $0,214(0,505)$ & $-0,538(0,071)$ \\
\hline toimintaa kontrolloivat ilmaukset & $-0,607(0,036)$ & $-0,623(0,031)$ \\
\hline huomiota uudelleen suuntaavat ilmaukset & $.0,413(0,182)$ & $-0,655(0,021)$ \\
\hline nimeämiset & $0,711(0,010)$ & $0,604(0,038)$ \\
\hline laajennokset & $0,606(0,037)$ & $0,664(0,018)$ \\
\hline kielentämiset & $0,732(0,007)$ & $-0,200(0,534)$ \\
\hline \multicolumn{3}{|l|}{ Toimintaa tukevat ilmaukset ja } \\
\hline toimintaa kontrolloivat ilmaukset & $0,034(0,916)$ & $0,043(0,895)$ \\
\hline huomiota uudelleen suuntaavat ilmaukset & $0,108(0,738)$ & $0,025(0,940)$ \\
\hline nimeämiset & $0,308(0,331)$ & $-0,056(0,862)$ \\
\hline laajennokset & $-0,011(0,974)$ & $-0,497(0,101)$ \\
\hline kielentämiset & $0,526(0,079)$ & $-0,263(0,409)$ \\
\hline \multicolumn{3}{|l|}{ Toimintaa kontrolloivat ilmaukset ja } \\
\hline huomiota uudelleen suuntaavat ilmaukset & $0,808(0,001)$ & $0,809(0,001)$ \\
\hline nimeämiset & $-0,624(0,030)$ & $-0,502(0,096)$ \\
\hline laajennokset & $.0,538(0,071)$ & $-0,466(0,127)$ \\
\hline kielentämiset & $.0,185(0,564)$ & $0,583(0,176)$ \\
\hline \multicolumn{3}{|l|}{ Huomiota uudelleen suuntaavat ilmaukset ja } \\
\hline nimeämiset & $-0,641(0,025)$ & $-0,659(0,020)$ \\
\hline laajennokset & $.0,402(0,195)$ & $-0,431(0,162)$ \\
\hline kielentämiset & $.0,195(0,544)$ & $0,011(0,974)$ \\
\hline \multicolumn{3}{|l|}{ Nimeämiset ja } \\
\hline laajennokset & $0,254(0,426)$ & $0,151(0,640)$ \\
\hline kielentämiset & $0,709(0,010)$ & $0,139(0,453)$ \\
\hline \multicolumn{3}{|l|}{ Laajennokset ja } \\
\hline kielentämiset & $0,049(0,879)$ & $-0,371(0,235)$ \\
\hline
\end{tabular}




\section{Äidin ilmausten ybteys lapsen sanaston kehitykseen}

Äidin erilaisten ilmausten yhteyttä lapsen ymmärtävän ja tuottavan sanaston tasoon 24 ja 30 kuukauden iässä tarkasteltiin Spearmanin järjestyskorrelaatiolla huomioiden ilmaisuluokkien absoluuttiset luvut ja myös suhteelliset osuudet (ks. taulukko 5). Äidin responsiivisuutta ja ohjailevuutta mittaavien muuttujien (analyysi 1) ja lapsen sanastomuuttujien väliltä ei löytynyt yhtään tilastollisesti merkitsevää yhteyttä. Kuitenkin äidin ilmaisuluokkien absoluuttisten lukujen osalta toimintaa tukevien ilmausten ja lapsen 30 kuukauden iässä mitatun ymmärtävän sanaston tason välillä oli suuntaa antava yhteys, joka oli negatiivinen. Tarkasteltaessa äidin ilmaisuluokkien suhteellisia osuuksia havaittiin, että responsiivisilla ilmauksilla oli positiivinen ja toimintaa kontrolloivilla ilmauksilla negatiivinen suuntaa antava yhteys lapsen tuottavan sanaston tasossa tapahtuneeseen muutokseen 24 ja 30 kuukauden välissä.

Äidin ilmausten analyysista 2 saatujen muuttujien (nimeämiset, laajennokset ja kielentämiset) ja lapsen sanastomuuttujien väliltä löytyi useita tilastollisesti merkitseviä yhteyksiä. Laajennosten positiivinen yhteys kaikkiin lapsen tuottavaa sanastoa mittaaviin muuttujiin on varsin selkeä, vaikkakin laajennosten absoluuttisen määrän osalta yhteys tuottavan sanaston tasoon 24 kuukauden iässä on vain suuntaa antava. Laajennosten suhteellisten osuuksien osalta löytyi lisäksi positiivinen yhteys niiden ja lapsen 30 kuukauden iässä mitatun ymmärtävän sanaston tason väliltä. Kielentämisten absoluuttisen märän yhteys lapsen ymmärtävän sanaston tasoon 30 kuukauden iässä oli puolestaan negatiivinen, samoin kuin kielentämisten suhteellisten osuuksien yhteys lapsen tuottavan sanaston tasoon 24 kuukauden iässä.

Lisäksi tutkittiin äidin ilmausten kokonaismäärän ja lasten sanaston tason välisiä yhteyksiä. Tilastollisesti merkitsevä negatiivinen korrelaatio löytyi ilmausten kokonaismäärän ja 30 kuukauden iässä arvioidun ymmärtävän sanaston tason välillä $(\mathrm{rs}=-0,709, \mathrm{p}=0,010)$. Äidin ilmausten kokonaismäärän ja tuottavan sanaston tason välillä ei löytynyt tilastollisesti merkitseviä yhteyksiä. 


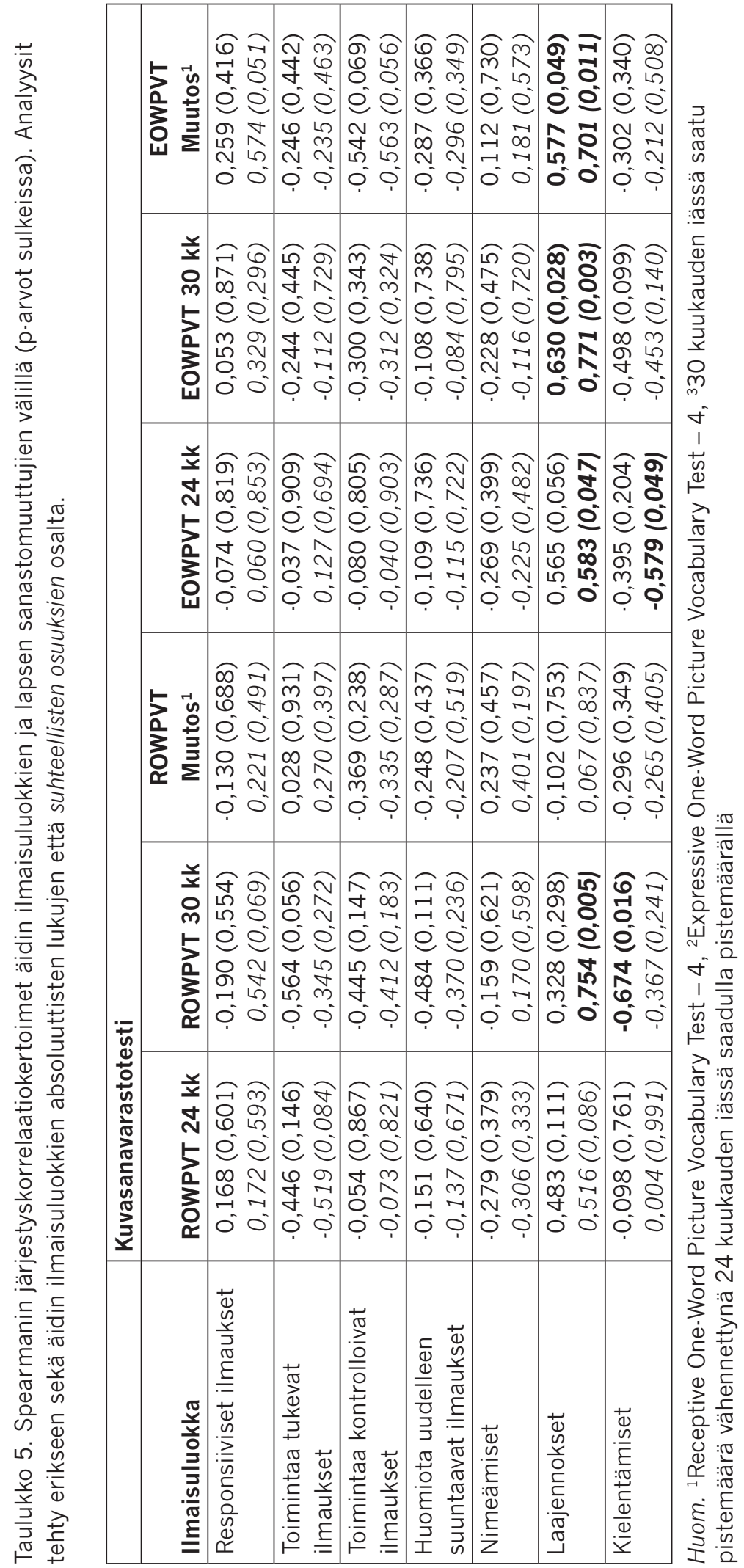




\section{POHDINTA}

Tässä tutkimuksessa äitien 2-vuotiaalle lapselleen suuntaamaa puhetta tarkasteltiin kahden erilaisen luokitteluanalyysin avulla. Ensimmäisessä analyysissa (analyysi 1) huomio kiinnitettiin responsiivisiin ja ohjaileviin ilmauksiin - erityisesti siihen, miten äidin ilmaukset liittyvät lapsen edellä olevaan ilmaukseen, huomion kohteeseen tai meneillään olevaan toimintaan. Toisessa luokitteluanalyysissa (analyysi 2) äitien ilmauksista poimittiin nimeämiset, laajennokset ja kielentämiset. Näillä kaikilla on kirjallisuuden mukaan merkitystä lapsen varhaisen sanaston kehittymisen kannalta (mm. Bornstein ym.,1999; Cable \& Domsch, 2011; Girolametto ym., 1999, 2002; Hoff \& Naigles, 2002; Kaiser \& Hancock, 2003; Masur ym., 2005; Roberts \& Kaiser, 2011; Smith ym., 2000; Tan \& Schafer, 2005; Wing ym., 2007). Tässä tutkimuksessa lasten sanaston taso arvioitiin 24 ja 30 kuukauden iässä. Sanastomittausten osalta ja myös äidin ilmaisutyyppien määrien ja ilmausten kokonaismäärän osalta huomioitiin mahdolliset erot tyttöjen ja poikien välillä. Lisäksi tarkasteltiin kaikkien analyysin kohteena olleiden lapselle suunnatun puheen piirteiden yhteyksiä toisiinsa. Lopuksi tutkittiin tarkasteltujen puheen piirteiden yhteyksiä lapsen sanaston tasoon sekä samassa ikäpisteessä eli 24 kuukauden iässä että puoli vuotta myöhemmin. Kyseinen ikävaihe on merkityksellinen arvioitaessa, onko varhaisessa puheen kehityksessä viivettä ja vastaavasti tarvetta tukitoimenpiteille.

Äitien ilmaisuluokkien osalta laskettiin sekä absoluuttiset määrät että suhteelliset osuudet. Flynn ja Masur (2007) ovat todenneet, että tarkasteltaessa suhteellisia osuuksia äidin vuorovaikutustyyli saattaa tulla puhtaammin esille kuin tarkasteltaessa absoluuttisia määriä. Tässä tutkimuksessa suhteellisia osuuksia tarkastelemalla pyrittiin kontrol- loimaan ilmausten määrästä johtuvia eroja äitien välillä, sillä äitien ilmausten määrä 15 minuutin videoidun leikkitilanteen aikana vaihteli huomattavasti. Aiemmissakin tutkimuksissa on kiinnitetty huomiota suureen yksilölliseen vaihteluun puhumisen määrässä (Hurtado ym., 2008; Rowe, 2008). Lisäksi tässä tutkimuksessa ilmausten määrä oli positiivisessa yhteydessä responsiivisten, toimintaa tukevien ja kielentävien ilmausten määrään. Näiden tulosten voidaan tulkita olevan ainakin jossain määrin samansuuntaisia kuin Rowella (2008) - mikäli responsiivisen ja ohjailevan vuorovaikutustyylin ajatellaan olevan toisilleen vastakkaisia - sillä Rowe löysi positiivisen yhteyden ohjailevien ilmausten ja vähäisemmän sanamäärän väliltä. Lisäksi tämän tutkimuksen tulokset osoittivat responsiivisten ilmausten määrän olevan negatiivisesti yhteydessä sekä toimintaa kontrolloivien että huomiota uudelleen suuntaavien ilmausten määrään. Tämä havainto on linjassa aiemman tutkimuksen kanssa, sillä responsiivisuuteen yhdistetään yleisesti äidin pyrkimys jakaa yhteinen huomion kohde lapsen kanssa jatkuvan lapsen huomiota uudelleen suuntaavan toiminnan sijaan (mm. Bornstein ym., 1999; Kaiser \& Hancock, 2003; Masur ym., 2005). Tulokset niin ikään osoittivat, että äideillä, joilla oli paljon lapsen toimintaa kontrolloivia ilmauksia, oli myös paljon huomiota uudelleen suuntaavia ilmauksia.

Mikään analyysista 1 saaduista äidin ilmaisuluokista (responsiiviset, toimintaa tukevat, toimintaa kontrolloivat ja huomiota uudelleen suuntaavat ilmaukset) ei ollut yhteydessä lapsen sanaston tasoon, vaikka joitakin suuntaa antavia yhteyksiä löytyi. Useat aiemmat tutkimukset, joissa on löydetty yhteys äidin responsiivisuuden ja lapsen kielellisen kehityksen väliltä, ovat keskittyneet noin yksivuotiaisiin lapsiin (mm. Bornstein ym., 1999; Paavola, 2006). Hoff ja Naigles (2002) tutkivat 2-vuotiaita lapsia ja ehdottivat löydös- 
tensä perusteella, että yksilölliset erot äitien tavoissa toimia vuorovaikutuksen aloittajana ja ylläpitäjänä eivät välttämättä selitä eroja lasten kehityksessä enää sen jälkeen, kun lapsi on oivaltanut kommunikoinnin tavoitteellisuuden ja oppinut toimimaan jaetun tarkkaavuuden tilanteissa (ks. myös Rowe, 2012; Soderstrom, 2007). On kuitenkin mahdollista, ettei asia ole ihan näin yksiselitteinen, sillä tässä tutkimuksessa löydettiin varsin korkea positiivinen korrelaatio äidin responsiivisten ilmausten ja lapsen tuottavan sanaston kehittymisen väliltä. Äidin responsiivisen vuorovaikutustyylin merkitys hieman myöhempään lapsen sanaston kehitykseen saattaa olla tietyllä tapaa välillinen, sillä tässä tutkimuksessa responsiivisten ilmausten määrä ja suhteellinen osuus olivat positiivisessa yhteydessä laajennosten määrän ja suhteelliseen osuuteen. Laajennokset puolestaan nousivat tässä tutkimuksessa merkityksellisimmäksi lapselle suunnatun puheen piirteeksi lapsen sanaston tason kannalta, erityisesti juurikin tuottavan sanaston osalta. Lapsen ilmaisun tulkitsemisella ja sen laajentamisella on aiempienkin tutkimusten mukaan yhteys lapsen tuottavaan puheeseen ja sanavaraston monipuolisuuteen (mm. Girolametto ym., 1999, 2002). Lapsen ilmaisun muotoilu uudelleen auttaa häntä uuden leksikaalisen tiedon käsittelyssä (Hoff \& Naigles, 2002; Kaiser \& Hancock, 2003; Roberts \& Kaiser, 2011; Wing ym., 2007). Lisäksi löydettiin suuntaa antava negatiivinen yhteys toimintaa kontrolloivien ilmausten ja lapsen tuottavan sanaston kehittymisen väliltä (vrt. Akhtar ym., 1991; Della Corte ym., 1983; Masur ym., 2005), mikä edelleen viittaa siihen, että äidin responsiivisella vuorovaikutustyylillä ja nimenomaan pyrkimyksellä jakaa yhteinen huomion kohde lapsen kanssa on merkitystä myös sanaston kehityksen varhaisvaiheiden jälkeen.

Hieman yllättävänä löydöksenä voidaan pitää sitä, että myös lapsen huomiota ylläpitävi- en ohjausten eli toimintaa tukevien ilmausten ja lapsen ymmärtävän sanaston tason välillä oli suuntaa antava negatiivinen yhteys. Tätä voisi kenties selittää lapsen vaikutuksilla vanhempaan (vrt. mm. Launonen, 2007, s. 20; Weitzner-Lin, 2004, s. 54). Äiti voi olla taipuvainen ottamaan suurempaa roolia vuorovaikutustilanteessa ja käyttämään enemmän ohjaavia ilmauksia, jos lapsi on kielellisessä kehityksessä vielä alkuvaiheissa. Samalla on kuitenkin mahdollista, etteivät ohjaavat ilmaukset ole kaikilta osin osuvia lapsen kielen kehityksen tason ja sen tukemisen kannalta, vaikka ne seuraisivatkin lapsen huomion suuntaa. Kuten Bornstein ym. (1999) ja Landry ym. (2006) toteavat, yksi kielen kehityksen tukemisen kannalta keskeinen lapselle suunnatun puheen elementti on se, että se on sovitettu lapsen sen hetkiseen kielelliseen tasoon. Tässä yhteydessä varsinaisia johtopäätöksiä asiasta ei kuitenkaan voi tehdä, sillä tässä tutkimuksessa äitien ilmausten sisältöä tai rakennetta ei analysoitu tarkemmin (esim. sanaston monipuolisuus, ilmaisujen pituudet).

Äideillä, joilla oli paljon responsiivisia ilmauksia, oli myös paljon nimeämisiä ja kielentämisiä. Kaksi viimeksi mainittua myös korreloivat positiivisesti keskenään. Nimeämisten yhteys lapsen toimintaa kontrolloiviin ja huomiota uudelleen suuntaaviin ilmauksiin oli puolestaan negatiivinen. Äidin nimeävien ilmausten määrä tai suhteellinen osuus ei tämän tutkimuksen mukaan ollut kuitenkaan merkityksellinen lapsen sanaston kehittymisen kannalta tarkastellussa ikävaiheessa. Nimeämisen määrä lienee merkityksellisintä aivan sanaston kehityksen varhaisvaiheissa (Cable \& Domsch, 2011; Tan \& Schafer, 2005). Kielentämisen ja lapsen sanaston tasoa mittaavien muuttujien väliltä löytyi kaksi yksittäistä, tilastollisesti merkitsevää yhteyttä. Nämä yhteydet olivat negatiivisia. Kielentäminen äidin puheen piirteenä saattaa korostua silloin, kun lapsi ei vielä juurikaan il- 
maise itseään puheella. Näin ollen tämä tulos voitaneen tulkita niin päin, että lapsen vielä vähäinen puheilmaisu on vaikuttanut äidin puheen piirteisiin. Kielentämällä lapsen toimintaa ja tilannetta yleensäkin äiti voi aloittaa ja ylläpitää vuorovaikutusta ilman, että lapsen tarvitsee vastata siihen sanallisesti (Vigil ym., 2005). Tällaisiin seikkoihin voi ainakin osittain liittyä myös löydetty negatiivinen yhteys äidin ilmausten määrän ja lapsen ymmärtävän sanaston tason välillä. Voidaan myös miettiä, ovatko kielentämiset aina välttämättä osuvia lapsen sen hetkiseen kielen ymmärtämisen tasoon nähden (vrt. Bornstein ym., 1999; Landry ym., 2006).

Tutkittavat lapset olivat tutkimushetkellä samanikäisiä, esitietojen perusteella tyypillisesti kehittyneitä ja suomenkielisiä. Yksilölliset erot lasten sanaston kehityksessä nousevat kuitenkin varsin selkeästi esille erityisesti siksi, että tutkittavien joukko on pieni. Tämän vuoksi tuloksia ei voida yleistää suurempaan joukkoon. Tutkimuksessa käytettyihin menetelmiin liittyy puolestaan seikkoja, jotka saattavat vaikuttaa tulosten luotettavuuteen: Käytettyjä kuvasanavarastotestejä ei ole vielä sovitettu eikä normitettu suomen kielelle. On myös syytä pohtia tässä tutkimuksessa analysoidun videoaineiston ja siitä saatavan tiedon edustavuutta. Videonäytteet olivat varsin lyhyitä, mutta niiden katsottiin kuitenkin olevan riittäviä tämän tyyppiseen tutkimukseen, sillä esimerkiksi Flynn ja Masur (2007) analysoivat vain kahdeksan minuutin mittaiset näytteet. Lisäksi leikkitilanteen kuvaaminen ja tutkijan läsnäolo kameran takana saattavat häiritä luonnollista vuorovaikutusta äidin ja lapsen välillä. Tilanne pyrittiin kuitenkin järjestämään mahdollisimman samalla tavalla kaikkien tutkittavien kohdalla. Joka tapauksessa luonnollisen vuorovaikutustilanteen analysointiin liittyy aina mahdollisuus, ettei analyysi ole kaikilta osin johdonmukainen, vaikka tässäkin tutkimuksessa käytettyjen analyysien luotettavuutta pyrittiin varmistamaan monin keinoin.

Näin ollen tutkimuksesta voidaan tehdä vain varovaisia johtopäätöksiä. Tulokset antavat kuitenkin viitteitä siitä, että äidin responsiivisella vuorovaikutustyylillä on ainakin välillisesti merkitystä lapsen sanaston kehityksen kannalta vielä aivan varhaisen kehitysvaiheen jälkeenkin. Tämä on hyvä ottaa huomioon puheterapeutin vastaanotolla, kun ohjataan puheen kehityksessä viivästyneen noin 2-3 vuotiaan lapsen vanhempia. Nimeämisten, laajennosten ja kielentämisen osalta huomiota saattaisi olla hyvä kiinnittää ennen kaikkea siihen, miten lapsen vähäisiäkin yrityksiä tuottaa sanoja voisi laajentaa. Tämä edellyttää kuitenkin sitä, että puheen ymmärtäminen on kehittynyt tyypillisesti. On mahdollista, että lapsi pystyy hyödyntämään laajennoksista saatavaa leksikaalista tietoa vielä paremmin kuin kielentämisistä saatavaa tietoa. Lisäksi tämä tutkimus ja myös esimerkiksi Namyn ja Nolanin (2004) tutkimus antavat viitteitä siitä, että yksittäisten sanojen nimeäminen ei enää 2-3 vuoden iässä tarjoa riittävää kielellistä virikettä - ei kenties edes siinä tapauksessa, että lapsen puheen kehitys olisi viivästynyt ja hän itse olisi vielä yksisanavaiheessa. Varmoja johtopäätöksiä tästä ei voi kuitenkaan vielä tehdä.

Lapselle suunnatun puheen tutkimus on tärkeää nimenomaan käytännön puheterapiatyön kannalta. Kaksivuotiaiden varhaisessa puheen kehityksessä viivästyneiden lasten ryhmä on heterogeeninen (Desmarais, Sylvestre, Meyer, Bairati \& Rouleau, 2008), ja siksi tässä ikäpisteessä on vielä hyvin vaikea ennustaa, onko kehitysviive ohimenevä vai onko puheen hitaan omaksumisen taustalla esimerkiksi kielellinen erityisvaikeus, jolloin ongelmat voivat jatkua hyvinkin pitkään. Tarvitaan lisää tietoa, minkälaisella vanhempien ohjauksella erityisessä riskiryhmässä olevien lasten puheen kehitystä voitaisiin tukea jo var- 
haisvaiheessa, jotta myöhempiä ongelmia voitaisiin mahdollisesti ehkäistä tai ainakin lieventää. Aihetta on tarpeen tutkia suuremmalla otoskoolla ja esimerkiksi tutkimusasetelmilla, joissa vertaillaan lapselle suunnatun puheen piirteitä tyypillisesti kehittyneille ja puheen kehityksessä viivästyneille lapsille. Tällaisessa tutkimuksessa olisi lisäksi tärkeä huomioida, onko kehitysviive vain puheen tuotossa vai myös puheen ymmärtämisessä, sillä tämä seikka oletettavasti vaikuttaa siihen, minkälaista puheesta saatavaa tietoa lapsen on mahdollista hyödyntää. Olisi myös tarpeen tutkia lisää muitakin kuin tässä tutkimuksessa tarkasteltuja lapselle suunnatun puheen piirteitä. Jatkotutkimuksissa kannattaisi suunnata huomiota erityisesti yli 2-vuotiaisiin lapsiin ja tarkastella esimerkiksi äitien ilmaisujen monipuolisuutta ja erilaisten sanojen käyttöä, sillä ne saattavat olla merkityksellisiä lapsen kielellistä kehitystä tukevia elementtejä aivan kehityksen varhaisvaiheiden jälkeen (Rowe, 2008, 2012).

\section{LÄHTEET}

Akhtar, N., Dunham, F. \& Dunham, P. (1991). Directive interactions and early vocabulary development: The role of joint attentional focus. Journal of Child Language, 18, 41-49.

Bates, E., Dale, P. \& Thal, D. (1995). Individual differences and their implications for theories of language development. Teoksessa P. Fletcher \& B. MacWhinney (toim.), The Handbook of Child Language (s. 96-151). Oxford: Blackwell Publishing.

Bergelson, E. \& Swingley, D. (2012). At 6-9 months, human infants know the meanings of many common nouns. Proceedings of the $\mathrm{Na}$ tional Academy of Sciences of the United States of America, 109, 3253-3258.

Bornstein, M. H., Tamis-LeMonda, C. S. \& Haynes, O. M. (1999). First words in the second year: Continuity, stability, and models of concurrent and predictive correspondence in vocabulary and verbal responsiveness across age and context. Infant Behavior and Development, $22,65-85$.
Cable, A. L. \& Domsch, C. (2011). Systematic review of the literature on the treatment of children with late language emergence. International Journal of Language \& Communication Disorders, 46, 138-154.

Clark, E. (2009). First language acquisition (2. painos). Cambridge, UK: Cambridge University Press.

Cross, T. (1977). Mothers' speech adjustments: The contributions of selected child listener variables. Teoksessa C. E. Snow \& C. A. Ferguson (toim.), Talking to children: Language input and acquisition (s. 151-188). Cambridge, UK: Cambridge University Press.

Della Corte, M., Benedict, H. \& Klein, D. (1983). The relationship of pragmatic dimensions of mothers' speech to the referential-expressive distinction. Journal of Child Language, 10, 34-43.

Desmarais, C., Sylvestre, A., Meyer, F., Bairati, I. \& Rouleau, N. (2008). Systematic review of the literature on characteristics of late-talking toddlers. International Journal of Language \& Communicative Disorders, 43, 361-389.

Fenson, L., Dale, P. S., Reznick, J. S., Bates, E., Thal, D. \& Pethick, S. J. (1994). Variability in early communicative development. Monographs of the Society for Research in Child Development, 59(5, Serial No. 242).

Flynn, V. \& Masur, E. (2007). Characteristics of maternal verbal style: Responsiveness and directiveness in two natural contexts. Journal of Child Language, 34, 519-543.

Girolametto, L., Bonifacio, S., Visini, C., Weitzman, E., Zocconi, E. \& Pearce P. S. (2002). Mother-child interactions in Canada and Italy: Linguistic responsiveness to late-talking toddlers. International Journal of Communication Disorders, 37, 153-171.

Girolametto, L., Weitzman, E., Wiigs, M. \& Pearce, P. (1999). The relationship between maternal language measures and language development in toddlers with expressive vocabulary delays. American Journal of Speech-Language Pathology, 8, 364-374.

Harris, M., Yeeles, C., Chasin, J. \& Oakley, Y. (1995). Symmetries and asymmetries in early lexical comprehension and production. Journal of Child Language, 22, 1-18. 
Harrison, L. J. \& McLeod, S. (2010). Risk and protective factors associated with speech and language impairment in a nationally representative sample of 4- to 5-year-old children. Journal of Speech, Language, and Hearing Research, 53, 508-529.

Hoff, E. (2003). The specificity of environmental influence: Socioeconomic status affects early vocabulary development via maternal speech. Child Development, 74, 1368-1378.

Hoff, E. \& Naigles, L. (2002). How children use input to acquire a lexicon. Child Development, 73, 418-433.

Hurtado, N., Marchman, V. A. \& Fernald, A. (2008). Does input influence uptake? Links between maternal talk, processing speed and vocabulary size in Spanish-learning children. Developmental Science 11, 31-39.

Huttenlocher, J., Waterfall, H. R., Vasilyeva, M., Vevea, J. L. \& Hedges, L. V. (2010). Sources of variability in children's language growth. Cognitive Psychology, 61, 343-365.

Kaiser, A. P. \& Hancock, T. B. (2003). Teaching parents new skills to support their young children's development. Infants \& Young Children, 16, 9-21.

Kuhl, P. K. (2007). Is speech learning 'gated' by the social brain? Developmental Science, 10, 110-120.

Kunnari, S. \& Välimaa, T. (2011). Lasten ymmärtävän sanaston arviointi kuvasanavarastotestillä. Teoksessa S. Stolt, M. Lehtihalmes, L. M. Heikkola \& S. Kunnari (toim.), Lasten ja nuorten pubeen ja kielen arviointi ja mittaaminen (s. 108-117). Helsinki: Puheen ja kielen tutkimuksen yhdistyksen julkaisuja 43.

Laalo, K. \& Kunnari, S. (2012). Hoivakieli. Teoksessa S. Kunnari \& T. Savinainen-Makkonen (toim.), Pienten sanat. Lasten ä̈̈nteellinen kehitys (s. 106-118). Jyväskylä: PS-kustannus.

Landry, S. H, Smith, K. E. \& Swank, P. R. (2006). Responsive parenting: Establishing early foundations for social, communication, and independent problem-solving skills. Developmental Psychology, 42, 627-642.

Launonen, K. (2007). Vuorovaikutus - kehitys, riskit ja tukeminen kuntoutuksen keinoin. Helsinki: Kehitysvammaliitto.

Lloyd, C. A. \& Masur, E. F. (2014). Infant behaviors influence mothers' provision of responsive and directive behaviors. Infant Behavior \& Development, 37, 276-285.

Lyytinen, P. (1999).Varhaisen kommunikaation ja kielen kehityksen arviointimenetelmä. Jyväskylä: Niilo Mäki Instituutti ja Jyväskylän yliopiston lapsitutkimuskeskus.

Martin, N. A. \& Brownell, R. (2010a). Expressive One-Word Picture Vocabulary Test - 4. Novato, CA: ATP Assessments.

Martin, N. A. \& Brownell, R. (2010b). Receptive One-Word Picture Vocabulary Test - 4. Novato, CA: ATP Assessments.

Masur, E. F., Flynn, V. \& Eichorst, D. L. (2005). Maternal responsive and directive behaviours and utterances as predictors of children's lexical development. Journal of Child Language, 32, 63-91.

Namy, L. L. \& Nolan, S. A. (2004). Characterizing changes in parent labelling and gesturing and their relation to early communicative development. Journal of Child Language, 31, 821-835.

Paavola, L. (2006). Maternal sensitive responsiveness, characteristics and relations to child early communicative and linguistic development. Väitöskirja. Acta Universitatis Ouluensis. Ser B. Vol. 73 .

Pan, B. A., Rowe, M. L., Singer, J. D. \& Snow, C. E. (2005). Maternal correlates of growth in toddler vocabulary production in low-income families. Child Development, 76, 763-782.

Pepper,J. \& Weitzmann, E. (2004). It Takes Two to Talk (4. painos, perustuu Ayala Hanen Manolsonin kirjoittamaan 3. painokseen). Toronto: The Hanen Centre.

Rescorla, L. (1989). The Language Development Survey: A screening tool for delayed language in toddlers. Journal of Speech and Hearing Disorders, 54, 587-599.

Roberts, M. Y. \& Kaiser, A. P. (2011). The effectiveness of parent-implemented language interventions: A meta-analysis. American Journal of Speech-Language Pathology, 20, 180-199.

Rowe, M. L. (2008). Child-directed speech: Relation to socioeconomic status, knowledge of child development and child vocabulary skill. Journal of Child Language, 35, 185-205.

Rowe, M. L. (2012). A longitudinal investigation of the role of quantity and quality of child-directed speech in vocabulary development. Child Development, 83, 1762-1774. 
Smith, K. E., Landry, S. H. \& Swank, P. R. (2000). Does the content of mothers' verbal stimulation explain differences in children's development of verbal and nonverbal cognitive skills? Journal of School Psychology, 38, 27-49.

Snow, C. E. (1977). The development of conversation between mothers and babies. Journal of Child Language, 4, 1-22.

Snow, C. E. (1995). Issues in the study of input: Finetuning, universality, individual and developmental differences, and necessary causes. Teoksessa P. Fletcher \& B. MacWhinney (toim.), The handbook of child language (s. 180-193). Oxford, UK: Blackwell.

Stoel-Gammon, C. (2011). Relationships between lexical and phonological development in young children. Journal of Child Language, $38,1-34$.

Stolt, S., Haataja, L., Lapinleimu, H. \& Lehtonen, L. (2008). Early lexical development of Finnish children - a longitudinal study. First Language, 28, 259-279.

Soderstrom, M. (2007). Beyond babytalk: Reevaluating the nature and content of speech input to preverbal infants. Developmental Review, $27,501-532$.
Tan, S. H. \& Schafer, G. (2005). Toddlers' novel word learning: Effects of phonological representation, vocabulary size and parents' ostensive behavior. First Language, 25, 131-155.

Vigil, D. C., Hodges, J. \& Klee, T. (2005). Quantity and quality of parental language input to late-talking toddlers during play. Child Language Teaching and Therapy, 21, 107-122.

Weitzner-Lin, B. (2004). Communication assessment and intervention with infants and toddlers. St. Louis, MO: Butterworth Heinemann.

Wing, C., Kohnert, K., Pham, G., Cordero, K. N., Ebert, K. D., Kan, P. F. \& Blaiser, K. (2007). Culturally consistent treatment for late talkers. Communication Disorders Quarterly, 29, 20-27.

Zubrick, S., Taylor, C., Rice, M. \& Slegers, D. (2007). Late language emergence at 24 months: An epidemiological study of prevalence, predictors and covariates. Journal of Speech, Language, and Hearing Research, 50, 1562-1592. 


\section{CHARACTERICTICS OF CHILD-DIRECTED SPEECH: RELATIONSHIPS TO VOCABULARY DEVELOPMENT AT 24 AND 30 MONTHS}

Leila Paavola-Ruotsalainen, Faculty of Humanities / Logopedics and the Child Language Research Center, University of Oulu

Heta Kemppainen, Rehabilitation Unit / Speech and Language Therapy, City of Kuopio

Beda Luopajärvi, Children's Rehabilitation Services, City of Espoo

This study explored child-directed speech of 12 mothers to their 2-year-old children during free play. Maternal child-directed speech was analysed for responsiveness and directiveness. In addition, the naming utterances, expansions, and descriptions were identified. Thereafter, correlational analyses were carried out to examine the relationships between different kinds of maternal utterances as well as their relationships to the measures of children's vocabulary at the age of 2 years and six months later. Individual variation in the number of maternal utterances was considerable. The total number of utterances correlated positively with the number of responsive utterances and descriptions. The results also implied that the responsive and directive interactive styles are contrary to each other. With regard to the facilitating role of child-directed speech to children's vocabulary development, according to this study the expansions were the most significant. Expansions also correlated positively with responsive utterances. It is advised to take these findings into account in speech and language therapy when advising parents of late-talking toddlers. There is a need for further investigations with larger sample sizes to make conclusions of the quality of child-directed speech and its role in vocabulary development with increased confidence. Future studies should also address the greater variety of characteristics of child-directed speech.

Keywords: child-directed speech, interactive style, supporting development, vocabulary 